\title{
The Role of Enterprise Resource Planning Systems ERP in Improving Customer Relationship Management CRM: An Empirical Study of Safeway Company of Jordan
}

\author{
Nader Aljawarneh ${ }^{1} \&$ Ziad Saleh Al-Omari $^{1}$ \\ ${ }^{1}$ School of Management, Jadara University, Irbid, Jordan \\ Correspondence: David Wolf II, School of Management, Jadara University, Irbid, Jordan. E-mail: \\ nadermsj@gmail.com.
}

Received: January 2, 2018

doi:10.5539/ijbm.v13n8p86

\begin{abstract}
The study aim is identifying the role of ERP systems in improving CRM at Safeway Company of Jordan. Employees (No. 210) at Safeway-Jordan were recruited in the study. The researcher adopted a diagnostic descriptive approach, and constructed two tests to measure; the ERP systems and CRM in Safeway-Jordan. The correlation between ERP systems and CRM at Safeway from employee's perspective was statistically significant. Considering the aforementioned findings, the study recommended that Safeway and other enterprises to use ERP systems and to implement them in prompting CRM for their effective role in improving CRM; it also recommends carefulness inhiring vendors and sales representatives.
\end{abstract}

Keywords: ERP systems, CRM, system quality, information quality, information integration, marketing, sales, selling, demand management, service center

\section{Introduction}

At the present time unprecedented technological developments have occurred in the field of software, systems and applications. Companies are confronted with tough competition in both local and global markets (Acosta, et al. 2013). Due to this rapid growth in the technological fields, business lives a competitive life (Qutaishat, et al, 2012). Rapid development in technology led to the emergence of terms that have changed the organizations dynamical operating patterns and changed work principals. Enterprises knew the dimensions of the competition and knew how to work. But this stability met tremendous and accelerating technological developments that adopt a massive amount of knowledge and information accumulation which created un-understandable competition. Therefore, the continuity of these enterprises depends on the level of applying and activating technology in different organizational, operational and administrative domains. And, to identify the technological dimensions of the organization and its optimal usage to achieve efficacy for continuity and goals achievement.

Therefore, efficient systems must be fully planned to be able to manage the resources properly and control them to reduce risk of expansion. ERP systems try to adapt to all types of organizations, whether it is service, commercial or industrial. ERP systems effectively link the available resources of these organizations with each other and create a kind of integration and flow of information between their different sections, because separate divisions of the organization cannot operate independently away from integration and effective connectivity which occurs by an efficient integrated information system that increases the efficacy of the organization information system ability and manage business processes efficiently. Therefore, ERP systems may assist organizations in integrating its processes by providing a computerized environment that includes a collective database to provide organized and compatible data and processes across all functions in time. (Monk \& Wagner, 2013)

Because of systems technological development, traditional marketing methods no longer focus on acquiring a competitive advantage for the organization as the twentieth century where products were commodities. Brands emerged to compensate for this minor perception, but soon they were abandoned because of inflexibility for mass marketing era. This led organizations to develop new strategies that fit the current interactive era to gain a sustainable competitive advantage from the information collected from customers. Organizations determined to build successful comfortable relations with customers by valuing them. This process starts with an ongoing 
strategy that transforms organization focus from traditional selling and manufacture to the customer with an increase in revenues and profits on current and long terms (Peppers \& Rogers, 2011).

The ability to communicate with customers constantly using a variety of different means for that reason is termed "customer relationship management (CRM)"; it provides the foundations that help organizations to develop and enhance customer's services and attract them. The increased competition in business world provoked companies to take interest in understanding customers and to interact with them for the reason of taking opportunities and facing challenges (Kostojohn et al., 2011).

Companies seek to develop and enhance good relations with customers, good communication results in development, sustainability, maintenance of the new competitiveness level the company reaches and to achieve uniqueness in performance. Customers are considered the engine and effective axe of all companies; CRM aims to persuade customers to repeat buying services by using best practices and methods to enhance customer loyalty and maintain it. Customer's services are rapidly changing, competition between companies is fierce, technological developments are growing and companies are looking for globalism, hence the Jordan Investment and Supply Company (Safeway) needs effective systems to manage procedures, workflow, control various processes, share data and information of different functional activities and reduce stocks waste to achieve competitiveness, sustainability, reduce costs, increase performance efficacy and manage customer's needs effectively.

Systems that change the nature of the relationship with customers include ERP systems. The problem of the study stems from the need to recognize the role of ERP systems and its dimensions (System Quality, Information Quality and Information Integration) in enhancing CRM and its dimensions (marketing, selling, demand management and service center) in Jordan Investment and Supply Company (Safeway), the study problem is explained by answering the study questions.

\subsection{The Study Questions}

The current study attempts to answer the main question of "what is the role of ERP systems in enhancing CRM at Jordan Investment and Supply Company (Safeway)?" several sub questions emerge from the main question:

1. What is the level of using ERP systems at Jordan Investment and Supply Company (Safeway)?

2. What is the level of applying CRM at Jordan Investment and Supply Company (Safeway)?

3. What is the effect of ERP systems dimensions (System Quality, Information Quality and Information Integration) in enhancing CRM and its dimensions (marketing, selling, demanding management and service center) in Jordan Investment and Supply Company (Safeway)?

\subsection{Importance of the Study}

The importance of the subject studied gives importance to the study. Customer's volume is of the main factors of success for any organization. Companies may plane strategies to manage customers relationships and to enhance them by ERP systems, the study is hoped to be a corner stone for further studies and to:

1. Guide researchers in ERP systems with the results and recommendations;

2. Help Jordan Investment and Supply Company (Safeway) managers in developing the relationship with customers by ERP systems;

3. Clarifies the effective role of the ERP systems in supporting CRM;

4. Assist organizations that are not using ERP systems to realize the importance of integration between ERP systems and CRM.

\subsection{The Study Objectives}

The study aims to recognize: the level of using ERP systems in CRM, the level of applying CRM and the role ERP systems in enhancing CRM in Jordan Investment and Supply Company (Safeway).

\subsection{The Study Model}

The study was based on two variables: the independent variable of ERP systems and its dimensions (system quality, information quality and information integration), and the dependent variable of CRM and its dimensions (marketing, selling, demand management and service center), the following diagram illustrates the model. 


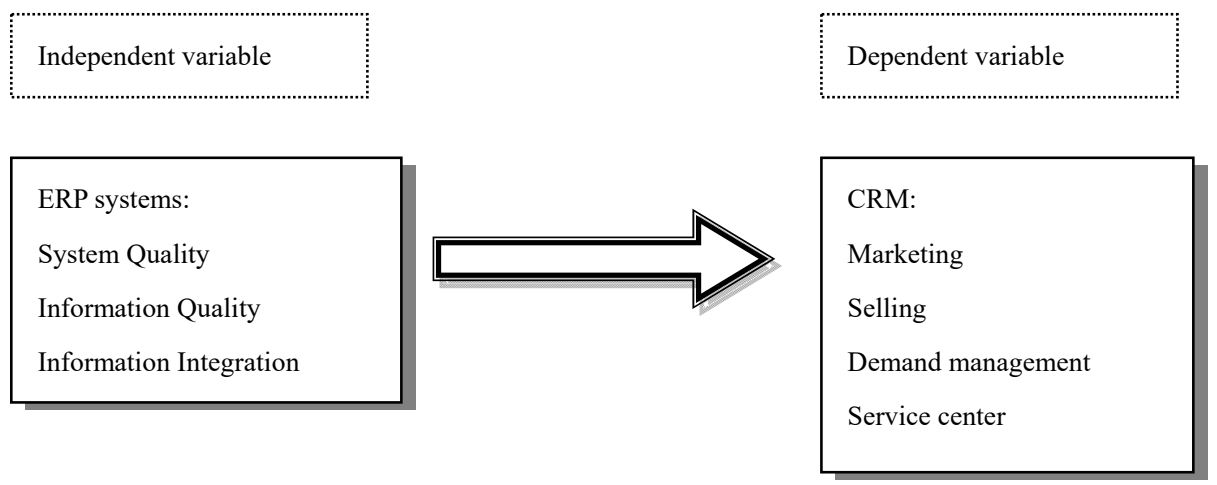

\section{Theoretical Framework}

\subsection{Enterprise Resource Planning Systems}

Because of business environment complexity, enterprises realized that the correct information at the right time helps build business relationships. Enterprise management needs an effective information system to improve services and reduce costs, thus increase competitiveness (Simunovic et al., 2013). Business environment fluctuations require ERP systems that quickly adjust its applications to the changes in the organization structure and standardized processes (Sarno et al., 2015) to link processes through a formal system and through the support tools to make decisions and achieve goals (Sheldon, 2005) by an integrated single Enterprise System (ES) (Laudon \& Laudon, 2012).

\subsection{The Concept of ERP Systems}

Computers were introduced to the business environment in the twentieth century, information systems were used in a limited range to serve one task such as accountancy or sales, hence organizations needed different systems to meet their various functions. This process led to repeated data and focus on administration without sharing data. In mid-nineties organizations started constructing ERP systems to computerize unite and integrate business processes to reach effective planning and control. RP systems offered employees from all administrative levels the ability to search through a variety of systems to find needed information and to use it from the same source of data (Bradford, 2014).

Matenda and Ogao (2013) said that applying ERP systems is different than applying traditional information systems; because of the integrated nature of ERP systems that cause radical changes on the work flow, organization structure and the way employees perform their duties.

Jeph (2013) defined information systems as a set of different components including devices, programs, communication infrastructure, individuals' organization to enhance planning, control, organization and decision taking.

ERP systems are software suited to business management functions that include purchasing, selling, stock management, human resources, financial resources and logistic services that provide a unified database for the organization to integrate and correlate with other organizations by a series of business procedures (Tsai \& Chou, 2015). This integration and correlation helps create a transparent information environment that enables senior managements to build informed expectations based on real-time data that describe the organization processes and the economy state (Tian \& Xu, 2015).

Yen, Idrus and Yousef (2014) defined ERP systems as a set of software that provides an integrated data transfer process between different functional areas for unifying them in one system environment, coordinating business processes, enhancing administrative structure between functional areas to ensure an integrated information system that includes systems processes within the organization including an organized database to enhance the organization stability, provide data storage which is easy to access and use in the stock control process, buying, selling, billing and personal loans accounting (Murthy, 2008).

Therefore, ERP systems work as the spine that correlate administrative thinking with marketing, buying, selling, manufacturing, planning ability and customer services to take a decision (Sheldon, 2005). Scholars define ERP systems as the best software of information exchange and synchronization of it between functional areas to integrate in a unified database to lead business effectively.

The main reason of ERP systems large number in the market is attributed to ERP systems quality, information 
integration and quality. The quality represents the systems' ability to achieve and meet what it was designed for with the lowest cost, the ability to perform the work in the right manner with the least time and effort, indicating excellence. Quality has many definitions that indicate excellence, match of specifications, and value for money and the flexibility extent in usage. ERP systems are the ultimate measure of products design and process engineering to ensure the quality of data to all functional divisions in manufacturing enterprises to recognize the repeated processes, to analyze main methods of problems, to enhance manufacturing methods continuously (Parthasarthy, 2007).

\subsection{System Quality}

Khlif and Jallouli, (2014) referred to system quality as the critical curve of the enterprise that maximizes revenues of investments for the need of users to manage technology and adopt systems. It is the ideal system that has infinite accuracy, uses its resources efficiently, is not aware of the external changes and is rebuilding in different applications. By implementing the system efficacy and accuracy limitations are found, the quality of the system is determined by several quality indicators some of which are: accuracy, strength and durability in holding secondary inputs, flexibility, efficacy and secondary outputs. (Veldhoven \& Roermund, 2011)

\subsection{Information Quality}

The organizations motivation to understand and enhance the information quality and data is important.Nowadays lots of organizations lost face to face communication with customers, suppliers and public organizational parties and employees, the basic correlation with those individuals and entities occur by the information circulated while exchanging goods and services. Verifying the data from personal communication in the supply chain may be hindered, which leads to problems in trying to understand enterprises because the data includes organizational contacts, so costs related to the information quality are hard to measure because it includes tangible and intangible components (Wang, et al, 2005). Thus, information quality should include five properties: accuracy, comprehensiveness, reliability, content and availability in a timely manner (Tsaia et al., 2012).

\subsection{Information Integration}

Wong et al. (2011) mentioned that information integration means sharing information of the enterprise infrastructure to support information exchange and coordinate between business functions and business associates, provide information integration for standardized organizations and digital information exchange through organization business activities to enable them to compete more effectively in the markets and to enable business associates of meeting their functional needs to enhance mutual performance. The goal of ERP systems is to achieve a high degree of integration to form widely spread information systems that work as an infrastructure of information integration in the basic business processes. If all these functions are easily integrated via a joint data base, efforts will not be lost in interpretation of the disorganized information within the organization. High integration levels enable any salesman to determine the best delivery date, feel confidence of demand information because it is not going to be lost, and know that sales communication expenses will be allocated to the correct location in the sales groups to be handled and paid quickly. (Murthy, 2008)

\subsection{The Concept of CRM}

The concept of CRM emerged because of the emergence of relationship marketing. The concept caught scholars and professionals interest in late 1990 (Soliman, 2011). Globalization brought about importance for competitiveness increase and fading of differences between companies, so providing customers with services became the central focus of these companies (Kubi \& Doku, 2011). CRM is considered a broad-based approach that constructs and widens relationships with customers, it is a business strategy that aims to understand, anticipate, manage and personalize current and potential customers of the organization. CRM is found in the heart of an idea strategy to create the mutual value for the parties involved in the business process, it creates a competitive sustainable advantage by better understanding and communication, it develops relationships with current customers and gain and maintain new ones (Hao, 2013). It is a combination of business and technology strategies (Khlif \& Jallouli, 2014), which helps business to focus on customers (Rodrigues, 2012). It is a strategic process to select customers and through them the company gains profit and interact with customers to maximize customer's current and future value (Kumar \& Reinartz, 2012). It is the strategic method that enables companies of using internal resources to manage the relationship with customers to create a competitive advantage to enhance company's performance (Mohamed \& Ben Rashid 2012). Scholars define CRM as the competitive advantage strategy of the company that aims to maintain current and future customers by a group of activities and procedures that interact directly with the customer to enhance the future vision of the company toward its customers and markets. 


\subsection{CRM System}

CRM was designed in early 1990 to support correlated with customers; to maintain customer's data, reach their preferences from previous purchases and communications, to manage sales teams and direct marketing (Bygstad \& Presthus, 2012). CRM was designed to formulate a set of vital tools to suit different industries and sizes of the companies to give them power to control, track and exchange customers data (Oren, 2015) to assist salesmen and promoters in analyzing customers behavior and give the company value by using technology and human resources (Bibiano, et al, 2014). So, companies competitiveness increase, maximize profits and reduce duplication of efforts and information storing efficacy and to make them available to all employees and offer customers and partners a unified overview. CRM system includes the methodologies, technologies and abilities that support a company in managing the relationship with the customer. A large part of this task is correlated directly in the development of information and communication technology that enables companies to collect the largest amount of information about their customers including their behavior and how to get in touch with them in as well as providing effective means and tools to manage this information. Therefore, the idea of CRM means enabling companies to manage customers better through inserting reliable systems, processes and procedures for the company to gather the largest amount of information about the customers and communicate for commercial purposes with them to collect detailed information that helps in targeting products, services and new markets (Ronchi, 2009).

\subsection{CRM Divisions (Marketing, Selling, Demand Management and Service Center)}

CRM is divided into marketing, selling, demand management and service center according to Chopra and Meindel (2007), the following is a brief review of each division:

1. Marketing. Marketing practices are all the activities that happen in interaction between the company and the external world, marketing is the process of developing products and services that benefit customers in return for an amount of money (Blythe, 2006).

The idea of customer being in the center of all marketing process is an effective axe that leads to marketing planning, this call for a start with the customer all the time, in many cases the customer and consumer is the same. Customer's right centrality means the company sought of the creative added value; customer's centrality is finding needs and meeting them rather than manufacturing products and selling them. Customer understanding is just the starting point that defines the overall needs of the customer (Blythe, 2009).

2. Selling. It is considered of the main foundations of business arc, it is a required part of buying process where interaction is important to meet the buyer's needs. It is a combination of the arts and processes that depend on the skillful usage of basic sales techniques of success. (Zimmerman, 2008)

3. Demand Management. It is the decision making and acting in time to track, evaluate and handle the demand in terms of planning and expectations. It is a process that ensures achieving balance between demand and supply between the departments of planning and prediction. The importance of demand management increases as a part of supply chain management expansion which earns organizations a competitive advantage, some organizations depend on supply chain in integrating abilities elements that face customers in demand management for a total formation of customers demand (Lapide, 2006).

4. Service Center. It refers to the first responder to the customer; it occurs through the interactive response unit employees who work partially or fully to serve customers. Several expectations are provided for the respondents to assist the employees in the planning process and to recognize the number of customers by calculating the percentage of respondents by telephone compared with the company website (Haimowitz, 2011). This means that call center jobs are supposed to be found in all companies. Most customers face problems or need answers talk to a person someone who helps to solve problems or answer questions (Sharon, 2013).

\subsection{ERP Systems and CRM}

CRM are designed to recognize and construct interactional relationships with customers, to collect develop and improve information, this is considered the external part of the company (Ruivoet al., 2014). ERP systems are designed to enable companies of reducing stocks levels and increase processes efficacy by organizing product manufacture processes, planning production processes and logistics management (Baran et al., 2008), representing the internal part of the company (Ruivo et al., 2014). Therefore, ERP systems provide data of sales, customer services, customer demand status, stock levels and management to assist CRM to recognize the latest expectations about sales by synchronizing the company with many databases (Goldenberg, 2008). As companies realized the need for knowledge about customers to compete and survive, the integration of ERP systems and CRM becomes critical (Ruivo et al., 2014). The border between ERP systems and CRM is cleared, when ERP 
systems end CRM begins to interact (Wittemann \& Ables, 2011).

Therefore, ERP systems concentrate on internal processes and resources management (such as, staff, finance and manufacturing), while CRM include marketing, selling, customer services and service center (Maleki \& Anand, 2008).

\section{Methodology and Hypotheses}

\subsection{Study Population and Sample}

The population is all male and female employees at Jordan Investment and Supply Company-Safeway total number of (300), out of which (35) employees were selected randomly as a pilot sample for tests validity purposes. The rest of the employees (265) were subjected to answer a questionnaire, from the retrieved questionnaires (245) only (210) were appropriate for statistical analysis, table 1 illustrates the sample distribution according to gender, experience, qualification and job title.

Table 1. Sample distribution according to gender, experience, qualifications and job title

\begin{tabular}{llll}
\hline Variable & Variables levels & Repetition & Percentage \\
\hline \multirow{4}{*}{ Gender } & Male & 148 & 70.5 \\
& Female & 62 & 29.5 \\
& Overall & $\mathbf{2 1 0}$ & $\mathbf{1 0 0}$ \\
& Less than 5 years & 115 & 54.8 \\
Experience & 5- $<10$ years & 49 & 23.3 \\
& 10- $<15$ years & 20 & 9.5 \\
& 15 and more & 26 & 12.4 \\
& Overall & $\mathbf{2 1 0}$ & $\mathbf{1 0 0}$ \\
Qualifications & Diploma and below & 76 & 36.2 \\
& Bachelor & 134 & 63.8 \\
& Overall & $\mathbf{2 1 0}$ & $\mathbf{1 0 0}$ \\
& Management & 40 & 19 \\
& Warehouse & 68 & 32.4 \\
\multirow{5}{*}{ Job title } & Marketing & 18 & 8.6 \\
& Salesmen & 40 & 19 \\
& Control & 15 & 7.1 \\
& Information technology & 29 & 13.8 \\
& Overall & $\mathbf{2 1 0}$ & $\mathbf{1 0 0}$ \\
\hline
\end{tabular}

\subsection{The Study Hypotheses}

The statement of the main Null hypothesis (H01):

There is no statistically significant difference at $(\alpha \leq 0.05)$ of ERP systems in enhancing CRM.

The primary hypothesis is subdivided into the following sub-hypotheses:

First sub-null hypothesis (H01-1):

There is no statistical difference at $(\alpha \leq 0.05)$ of ERP systems (system quality, system information and information integration) and marketing.

Second sub-null hypothesis (H01-2):

There is no statistical difference at $(\alpha \leq 0.05)$ of ERP systems (system quality, system information and information integration) and selling.

Third sub-null hypothesis (H01-3):

There is no statistical difference at $(\alpha \leq 0.05)$ of ERP systems (system quality, system information and information integration) and demand management.

Fourth sub-null hypothesis (H01-4):

There is no statistical difference at $(\alpha \leq 0.05)$ of ERP systems (system quality, system information and information integration) and service center. 


\subsection{Study Tests}

The study utilized two tests;

First. The Jordan Investment and Supply Company-Safeway ERP system level.

Construct validity of ERP system level. Items internal consistency is calculated using a pilot sample of (35) employees. Correlations between items and dimensions of ERP systems are calculated by Pearson correlation as shown in table 2.

Table 2. Correlation coefficients of ERP systems and inter-correlation of the dimensions

\begin{tabular}{llllll}
\hline Relationship & Statistics & $\begin{array}{l}\text { System quality of } \\
\text { Safeway } \\
\text { Enstems }\end{array}$ & $\begin{array}{l}\text { Information quality of } \\
\text { Safeway ERP systems }\end{array}$ & $\begin{array}{l}\text { Information integration of } \\
\text { Safeway ERP systems }\end{array}$ \\
\hline Systemquality of Safeway & Correlation coefficient & 0.66 & & & \\
ERP systems & Sign. & 0.00 & 0.68 & \\
Informationquality & Correlation coefficient & 0.59 & 0.00 & \\
Safeway ERP systems & Sign. & 0.00 & 0.89 & 0.88 \\
overall & Correlation coefficient & 0.86 & 0.00 & 0.00 \\
& Sign. & 0.00 & & \\
\hline
\end{tabular}

From table 2 it is inferred that the correlation coefficient values of the dimension ranged between $(0.86-0.89)$; and the intercorrelation values ranged between (0.59-0.68). Correlation coefficient values of each item with the dimensions of ERP scores was not $(<0.20)$, these results refer to good construction validity. (Odeh, 2014)

\subsection{ERP systems Reliability}

The Items internal consistency was calculated by Cronbach Alpha using the answers of the pilot sample. Reliability was insured through the retesting the pilot sample after an interval of two weeks, the retest reliability was calculated between by Pearson correlation as shown in table 3 .

Table 3. Cronbach Internal Consistency Coefficient values and test-retest reliability of ERP systems dimensions and overall test

\begin{tabular}{lllc}
\hline Dimensions & Internal consistency & Repetition & Item No. \\
\hline System quality of Safeway ERP systems & 0.87 & 0.84 & 9 \\
Information quality of Safeway ERP systems & 0.88 & 0.87 & 8 \\
Information integration of Safeway ERP systems & 0.91 & 0.86 & 8 \\
Overall & 0.94 & 0.83 & 25 \\
\hline
\end{tabular}

Internal consistency of ERP scored (0.94), and the dimensions scores ranged between (0.87-0.91), the test re-test values scored (0.83) degrees and the dimensions scores ranged between (0.84-0.87) as table 3 illustrated.

\section{Second. The Jordan Investment and Supply Company-Safeway CRM level}

\subsection{Construct validity of CRM Level}

CRM internal consistency was calculated by using the pilot sample of the study. Correlations between items and dimensions of CRM level were calculated by Pearson correlation as shown in table 4 .

Table 4. Overall CRM correlation coefficients and inter-correlations coefficients of the dimensions

\begin{tabular}{|c|c|c|c|c|c|}
\hline Correlation & Statistics & Marketing & Selling & Demand management & Service center \\
\hline \multirow{2}{*}{ Selling } & Correlation coefficient & 0.70 & & & \\
\hline & Sign. & 0.00 & & & \\
\hline \multirow{2}{*}{ Demand management } & Correlation coefficient & 0.64 & 0.77 & & \\
\hline & Sign. & 0.00 & 0.00 & & \\
\hline \multirow{2}{*}{ Servicecenter } & Correlation coefficient & 0.55 & 0.69 & 0.71 & \\
\hline & Sign. & 0.00 & 0.00 & 0.00 & \\
\hline \multirow{2}{*}{ Overall } & Correlation coefficient & 0.85 & 0.90 & 0.89 & 0.84 \\
\hline & Sign. & 0.00 & 0.00 & 0.00 & 0.00 \\
\hline
\end{tabular}


From table 4 it is inferred that the correlation coefficient values of the dimension ranged between (0.84- 0.90); and the intercorrelation values ranged between $(0.55-0.77)$. These results refer to acceptable construction validity.

\subsection{CRM Reliability}

The Items internal consistency was calculated by Cronbach Alpha using the answers of the pilot sample. Reliability was insured through retesting the pilot sample after an interval of two weeks, the retest reliability was calculated by Pearson correlation as shown in table 5 .

Table 5. Cronbach Internal Consistency Coefficient values and test-retest reliability of CRM dimensions and overall test

\begin{tabular}{llll}
\hline Dimension & Internal consistency & Repetition & Item No. \\
\hline Marketing & 0.91 & 0.83 & 11 \\
Selling & 0.90 & 0.87 & 9 \\
Demand Management & 0.90 & 0.85 & 10 \\
Service Center & 0.90 & 0.86 & 9 \\
Overall & 0.96 & 0.84 & 39 \\
\hline
\end{tabular}

Table 5 illustrated that internal consistency of CRM scored (0.96) degrees, and the dimensions scores ranged between $(0.90-0.91)$, the test re-test values scored $(0.84)$ degrees and the dimensions scores ranged between (0.83-0.87) degrees.

\section{Analysis and Results}

This study objective was to identify the level of using ERP systems in Investment and Supply Company (Safeway-Jordan), to identify the level of applying CRM in the enterprise; and to identify the role of ERP systems in improving CRM by attempting to answer the study questions.

To answer the first question of "What is the level of using ERP systems at Jordan Investment and Supply Company (Safeway)?" means and standard deviations of ERP systems and its dimensions at Safeway from the employee's perspective are calculated as illustrated in table 6.

Table 6. Means and standard deviations of ERP systems and its dimensions at Safeway from employee's perspective based on means descendent order

\begin{tabular}{llllll}
\hline Rank & No. & ERP systems dimensions & M. & SD. & Level \\
\hline 1 & 1 & ERP quality systems & 3.91 & 0.55 & High \\
2 & 2 & ERP information quality & 3.85 & 0.60 & High \\
3 & 3 & ERP information integration & 3.80 & 0.68 & High \\
\hline
\end{tabular}

Table 6 illustrates that ERP systems at Safeway from employee's perspective was high. System Quality was ranked first, information quality followed and was ranked second and finally information integration was ranked third.

To answer the second question of "What is the level of applying Customer Relationship Management (CRM) at Jordan Investment and Supply Company (Safeway)?" means and standard deviations of CRM and its dimensions at Safeway from the employee's perspective were calculated and ranked based on means descendent order as illustrated in table 7.

Table 7. Means and standard deviations of CRM and its dimensions at Safeway from employee's perspective based on means descendent order

\begin{tabular}{llllll}
\hline Rank & Item No. & CRM dimensions & M. & SD. & Level \\
\hline 1 & 4 & Service center & 4.03 & 0.59 & High \\
2 & 1 & Marketing & 4.00 & 0.63 & High \\
3 & 2 & Selling & 3.93 & 0.63 & High \\
4 & 3 & Demand management & 3.93 & 0.60 & High \\
Overall & & & 3.97 & & High \\
\hline
\end{tabular}


Table 7 illustrates that CRM at Safeway from employee's perspective was high. Service center was ranked first, marketing was ranked second, selling came third last scored demand management and was ranked fourth.

To answer the third question of "What is the effect of ERP (System Quality, Information Quality and Information Integration) in enhancing customer relationship management (marketing, sales, demand management and service center) in Jordan Investment and Supply Company (Safeway)?" means and standard deviations of the relationship between ERP systems and CRM was calculated as table 8 presents.

Table 8. Means and standard deviations of CRM dimensions at Safeway from employee's perspective

\begin{tabular}{lllllll}
\hline Correlation & Statistics & CRM & Marketing & Selling & Demand management & Service center \\
\hline \multirow{2}{*}{ Marketing } & Correlation coefficient & $\mathbf{0 . 8 5}$ & & & & \\
\multirow{5}{*}{ Selling } & Sign. & 0.00 & & & & \\
\multirow{5}{*}{ Demand management } & Correlation coefficient & $\mathbf{0 . 9 0}$ & $\mathbf{0 . 7 0}$ & & & \\
& Sign. & 0.00 & 0.00 & & \\
Service center & Correlation coefficient & $\mathbf{0 . 8 9}$ & $\mathbf{0 . 6 4}$ & $\mathbf{0 . 7 7}$ & \\
& Sign. & 0.00 & 0.00 & 0.00 & & \\
\multirow{2}{*}{ Safeway ERPsystems } & Correlation coefficient & $\mathbf{0 . 8 4}$ & $\mathbf{0 . 5 5}$ & $\mathbf{0 . 6 9}$ & $\mathbf{0 . 7 1}$ & \\
& Sign. & 0.00 & 0.00 & 0.00 & 0.00 & \\
& Correlation coefficient & $\mathbf{0 . 6 7}$ & $\mathbf{0 . 6 0}$ & $\mathbf{0 . 6 1}$ & $\mathbf{0 . 5 9}$ & $\mathbf{0 . 5 4}$ \\
& Sign. & 0.00 & 0.00 & 0.00 & 0.00 & 0.00 \\
\hline
\end{tabular}

As table 8 illustrates 15 out of 15 positive correlations are found at $\alpha=0.05$, multiple regression analysis was performed to detect the predictive ability of the predictive model as illustrated in table 9 , based on the predictive variables insertion on the regression equation (Enter).

Table 9. Results of the regression equation and multiple correlation coefficient of CRM test, its interpretation degree based on the variables insertion to the regression equation

\begin{tabular}{|c|c|c|c|c|c|c|c|c|c|}
\hline \multirow{2}{*}{$\begin{array}{l}\text { Predictive } \\
\text { model }\end{array}$} & & \multirow{2}{*}{$\mathbf{R}$} & \multirow{2}{*}{$\mathbf{R}^{2}$} & \multirow{2}{*}{$\begin{array}{l}\text { Adjusted } \\
\mathbf{R}^{2}\end{array}$} & \multirow{2}{*}{$\begin{array}{l}\text { Std. Error of the } \\
\text { Estimate }\end{array}$} & \multicolumn{4}{|c|}{ Change statistics } \\
\hline & & & & & & F value & Df1 & Df2 & Sig \\
\hline $1 *$ & CRM & 0.67 & 0.4516 & 0.4489 & 0.40 & 171.27 & 1 & 208 & 0.00 \\
\hline $2 *$ & Marketing & 0.60 & 0.3547 & 0.3516 & 0.50 & 114.32 & 1 & 208 & 0.00 \\
\hline $3 *$ & Selling & 0.61 & 0.3668 & 0.3637 & 0.50 & 120.47 & 1 & 208 & 0.00 \\
\hline $4^{*}$ & $\begin{array}{l}\text { Demand } \\
\text { management }\end{array}$ & 0.59 & 0.3527 & 0.3495 & 0.49 & 113.31 & 1 & 208 & 0.00 \\
\hline $5^{*}$ & Service center & 0.54 & 0.2877 & 0.2843 & 0.50 & 84.02 & 1 & 208 & 0.00 \\
\hline$*$ & Predicting vari & ressior & stability); & Safeway ER & stems & & & & \\
\hline
\end{tabular}

From table 9 it is observed that the predictive model ERP systems and the predicted modelCRM from Safeway employee's perspective was significant at $\alpha=0.05$, the relative impact explained $45.16 \%$ from the overall explanatory variance of CRM. The table also illustrates that ERP systems predicted the variable of marketing level at $\alpha=0.05$, the relative impact explained $35.47 \%$ from the overall explanatory variance. ERP systems predicted the variable of selling level at $\alpha=0.05$, the relative impact explained $36.68 \%$ from the overall explanatory variance. ERP systems predicted the variable of demand management level at $\alpha=0.05$, the relative impact explained $35.27 \%$ from the overall explanatory variance. ERP systems predicted the variable of service center level at $\alpha=0.05$, the relative impact explained $28.77 \%$ from the overall explanatory variance. 
Table 10. Standard and nonstandard weights of ERP systems and CRM and its dimensions from Safeway employees perspective

\begin{tabular}{|c|c|c|c|c|c|c|c|}
\hline \multirow[t]{2}{*}{ Predictive model } & \multirow[t]{2}{*}{ Predicted variables } & \multirow[t]{2}{*}{ Predictors } & \multirow{2}{*}{$\begin{array}{l}\text { Non } \\
\text { standards } \\
\text { weights } \\
\text { B } \\
\end{array}$} & \multicolumn{2}{|c|}{ Standard weights } & \multirow[t]{2}{*}{$\begin{array}{l}\text { t } \\
\text { value }\end{array}$} & \multirow[t]{2}{*}{ Sign. } \\
\hline & & & & Std. Error & $B$ & & \\
\hline \multirow{2}{*}{ CRM } & \multirow{2}{*}{1} & (regression stability) & 1.36 & 0.20 & & 6.76 & 0.00 \\
\hline & & Safeway ERP systems & 0.68 & 0.05 & 0.67 & 13.09 & 0.00 \\
\hline \multirow{2}{*}{ Marketing } & \multirow{2}{*}{2} & (regression stability) & 1.28 & 0.26 & & 4.98 & 0.00 \\
\hline & & Safeway ERP systems & 0.71 & 0.07 & 0.60 & 10.69 & 0.00 \\
\hline \multirow{2}{*}{ Selling } & \multirow{2}{*}{3} & (regression stability) & 1.16 & 0.26 & & 4.54 & 0.00 \\
\hline & & Safeway ERP systems & 0.72 & 0.07 & 0.61 & 10.98 & 0.00 \\
\hline \multirow{2}{*}{ Demand management } & \multirow{2}{*}{4} & (regression stability) & 1.31 & 0.25 & & 5.31 & 0.00 \\
\hline & & Safeway ERP systems & 0.68 & 0.06 & 0.59 & 10.64 & 0.00 \\
\hline \multirow{2}{*}{ Service center } & \multirow{2}{*}{5} & (regression stability) & 1.72 & 0.26 & & 6.72 & 0.00 \\
\hline & & Safeway ERP systems & 0.60 & 0.07 & 0.54 & 9.17 & 0.00 \\
\hline
\end{tabular}

From table 10 we notice that when ERP systems level increased from Safeway employees' perspective by one standard unit, CRM level increased by 0.67 of the standard unit. The predictive variable was functional at $(\alpha=0.05)$. The increase of ERP systems level by one standard unit increased marketing level by 0.60 of the standard unit. The predictive variable was functional at $(\alpha=0.05)$.

Also to answer the third question linear correlation coefficients values of ERP and CRM were calculated as illustrated in table 11 .

Table 11. Values of inter-correlation coefficients of the predictive and predicting variables

\begin{tabular}{|c|c|c|c|c|c|c|c|c|}
\hline Relationship & Statistics & CRM & Marketing & Selling & $\begin{array}{l}\text { Demand } \\
\text { management }\end{array}$ & $\begin{array}{l}\text { Service } \\
\text { center }\end{array}$ & $\begin{array}{l}\text { System } \\
\text { quality in } \\
\text { Safeway } \\
\text { ERP } \\
\text { systems }\end{array}$ & $\begin{array}{l}\text { Information } \\
\text { quality in } \\
\text { Safeway ERP } \\
\text { systems }\end{array}$ \\
\hline \multirow[t]{2}{*}{ Marketing } & $\begin{array}{l}\text { Correlation } \\
\text { coefficient }\end{array}$ & 0.85 & & & & & & \\
\hline & Sign. & 0.00 & & & & & & \\
\hline \multirow[t]{2}{*}{ Selling } & $\begin{array}{l}\text { Correlation } \\
\text { coefficient }\end{array}$ & 0.90 & 0.70 & & & & & \\
\hline & Sign. & 0.00 & 0.00 & & & & & \\
\hline \multirow{2}{*}{$\begin{array}{l}\text { Demand } \\
\text { management }\end{array}$} & $\begin{array}{l}\text { Correlation } \\
\text { coefficient }\end{array}$ & 0.89 & 0.64 & 0.77 & & & & \\
\hline & Sign. & 0.00 & 0.00 & 0.00 & & & & \\
\hline \multirow[t]{2}{*}{ Service center } & $\begin{array}{l}\text { Correlation } \\
\text { coefficient }\end{array}$ & 0.84 & 0.55 & 0.69 & 0.71 & & & \\
\hline & Sign. & 0.00 & 0.00 & 0.00 & 0.00 & & & \\
\hline $\begin{array}{l}\text { System quality in } \\
\text { Safeway ERP }\end{array}$ & $\begin{array}{l}\text { Correlation } \\
\text { coefficient }\end{array}$ & 0.51 & 0.50 & 0.47 & 0.44 & 0.37 & & \\
\hline systems & Sign. & 0.00 & 0.00 & 0.00 & 0.00 & 0.00 & & \\
\hline $\begin{array}{l}\text { Information quality } \\
\text { in Safeway ERP }\end{array}$ & $\begin{array}{l}\text { Correlation } \\
\text { coefficient }\end{array}$ & 0.55 & 0.46 & 0.50 & 0.51 & 0.44 & 0.66 & \\
\hline systems & Sign. & 0.00 & 0.00 & 0.00 & 0.00 & 0.00 & 0.00 & \\
\hline $\begin{array}{l}\text { Information } \\
\text { integration }\end{array}$ & $\begin{array}{l}\text { Correlation } \\
\text { coefficient }\end{array}$ & 0.69 & 0.59 & 0.61 & 0.60 & 0.58 & 0.59 & 0.68 \\
\hline $\begin{array}{l}\text { Safeway } \\
\text { systems }\end{array}$ & Sign. & 0.00 & 0.00 & 0.00 & 0.00 & 0.00 & 0.00 & 0.00 \\
\hline
\end{tabular}

Table 11 illustrates that all the correlations are functionally positive at $(\alpha=0.05)$. The predictive ability is detected by applying multiple regression analysis based on stepwise method as table 12 illustrates. 
Table 12. Results of the regression hypothesis test of CRM, its correlation coefficient and its interpretation degree based on variables insertion to the regression equation

\begin{tabular}{|c|c|c|c|c|c|c|c|c|c|c|c|}
\hline \multirow{2}{*}{$\begin{array}{l}\text { Main } \\
\text { predictive } \\
\text { model }\end{array}$} & \multirow{2}{*}{$\begin{array}{l}\text { Predicted } \\
\text { variables }\end{array}$} & \multirow{2}{*}{$\begin{array}{l}\text { Sub } \\
\text { predictive } \\
\text { model }\end{array}$} & \multirow{2}{*}{$\mathbf{R}$} & \multirow{2}{*}{$\mathbf{R}^{2}$} & \multirow{2}{*}{ Adjusted $\mathbf{R}^{2}$} & \multicolumn{3}{|c|}{ Change statistics } & \multirow[b]{2}{*}{$\begin{array}{l}\text { upper } \\
\text { degree }\end{array}$} & \multirow[b]{2}{*}{$\begin{array}{l}\text { lower } \\
\text { degree }\end{array}$} & \multirow[b]{2}{*}{ sign. } \\
\hline & & & & & & Estimates & $\begin{array}{l}\mathbf{R}^{2} \\
\text { Change }\end{array}$ & F change & & & \\
\hline \multirow{4}{*}{1} & \multirow{4}{*}{ CRM } & $1^{\mathrm{A}}$ & 0.7 & 0.472 & 0.4693 & 0.39 & 0.4718 & 185.8 & 1 & 208 & 0.00 \\
\hline & & $2^{\mathrm{B}}$ & 0.70 & 0.49 & 0.4847 & 0.38 & 0.0178 & 7.23 & 1 & 207 & 0.01 \\
\hline & & $\mathrm{A}$ & \multicolumn{9}{|c|}{ predicting variables: (regression stability), information integration of Safeway ERP systems } \\
\hline & & $\mathrm{B}$ & \multicolumn{9}{|c|}{$\begin{array}{l}\text { predicting variables: (regression stability), information integration of Safeway ERP systems; } \\
\text { system quality of Safeway ERP systems }\end{array}$} \\
\hline \multirow{4}{*}{2} & \multirow{4}{*}{ Marketing } & $1^{\mathbf{A}}$ & 0.6 & 0.352 & 0.3485 & 0.50 & 0.3516 & 112.79 & 1 & 208 & 0.00 \\
\hline & & $2^{\mathrm{B}}$ & 0.6 & 0.384 & 0.3781 & 0.49 & 0.0324 & 10.89 & 1 & 207 & 0.00 \\
\hline & & A & \multirow{2}{*}{\multicolumn{9}{|c|}{$\begin{array}{l}\text { predicting variables: (regression stability), information integration of Safeway ERP systems } \\
\text { predicting variables: (regression stability), information integration of Safeway ERP systems; } \\
\text { system quality of Safeway ERP systems }\end{array}$}} \\
\hline & & $\mathrm{B}$ & & & & & & & & & \\
\hline \multirow{4}{*}{3} & \multirow{4}{*}{ Selling } & $1^{\mathbf{A}}$ & 0.6 & 0.369 & 0.3664 & 0.50 & 0.3694 & 121.84 & 1 & 208 & 0.00 \\
\hline & & $2^{\mathrm{B}}$ & 0.6 & 0.388 & 0.3823 & 0.49 & 0.0189 & 6.38 & 1 & 207 & 0.01 \\
\hline & & A & \multicolumn{9}{|c|}{ predicting variables: (regression stability), information integration of Safeway ERP systems } \\
\hline & & $\mathrm{B}$ & \multicolumn{9}{|c|}{$\begin{array}{l}\text { predicting variables: (regression stability), information integration of Safeway ERP systems; } \\
\text { system quality of Safeway ERP systems }\end{array}$} \\
\hline \multirow{4}{*}{4} & \multirow{4}{*}{$\begin{array}{l}\text { Demand } \\
\text { management }\end{array}$} & $1^{\mathbf{A}}$ & 0.60 & 0.366 & 0.3626 & 0.48 & 0.3656 & 119.88 & 1 & 208 & 0.00 \\
\hline & & $2^{\mathrm{B}}$ & 0.6 & 0.382 & 0.3756 & 0.48 & 0.0159 & 5.34 & 1 & 207 & 0.02 \\
\hline & & A & \multicolumn{9}{|c|}{ predicting variables: (regression stability), information integration of Safeway ERP systems } \\
\hline & & $\mathrm{B}$ & \multicolumn{6}{|c|}{$\begin{array}{l}\text { predicting variables: (regression stability), information integration } \\
\text { system quality of Safeway ERP systems }\end{array}$} & of Safe & ay ERP & stems; \\
\hline \multirow{2}{*}{5} & Service & $1^{\mathrm{A}}$ & 0.6 & 0.34 & 0.337 & 0.48 & 0.3402 & 107.23 & 1 & 208 & 0.00 \\
\hline & center & A & \multicolumn{9}{|c|}{ predicting variables: (regression stability), information integration of Safeway ERP systems } \\
\hline
\end{tabular}

Table 12 illustrates that the effect of Safeway ERP systems (system quality, information quality and information integration) and its dimensions from the perspective of employees was significant at $(\alpha=0.05)$ in predicting CRM from the perspective of employees. The combined impact of the independent variables explained $48.96 \%$. Information integration relative impact explained $47.18 \%$ and the system quality explained $1.78 \%$.

Safeway ERP systems (system quality, information quality and information integration) and its dimensions was significant at $\alpha=0.05$ in predicting the variable of marketing from Safeway employees perspective. The combined impact of the independent variables explained $38.40 \%$ of the results, information integration relative impact explained $35.16 \%$ and the system quality explained $3.34 \%$. 
Table 13. Standard and nonstandard weight of ERP systems of CRM and its dimensions from Safeway employee's perspective

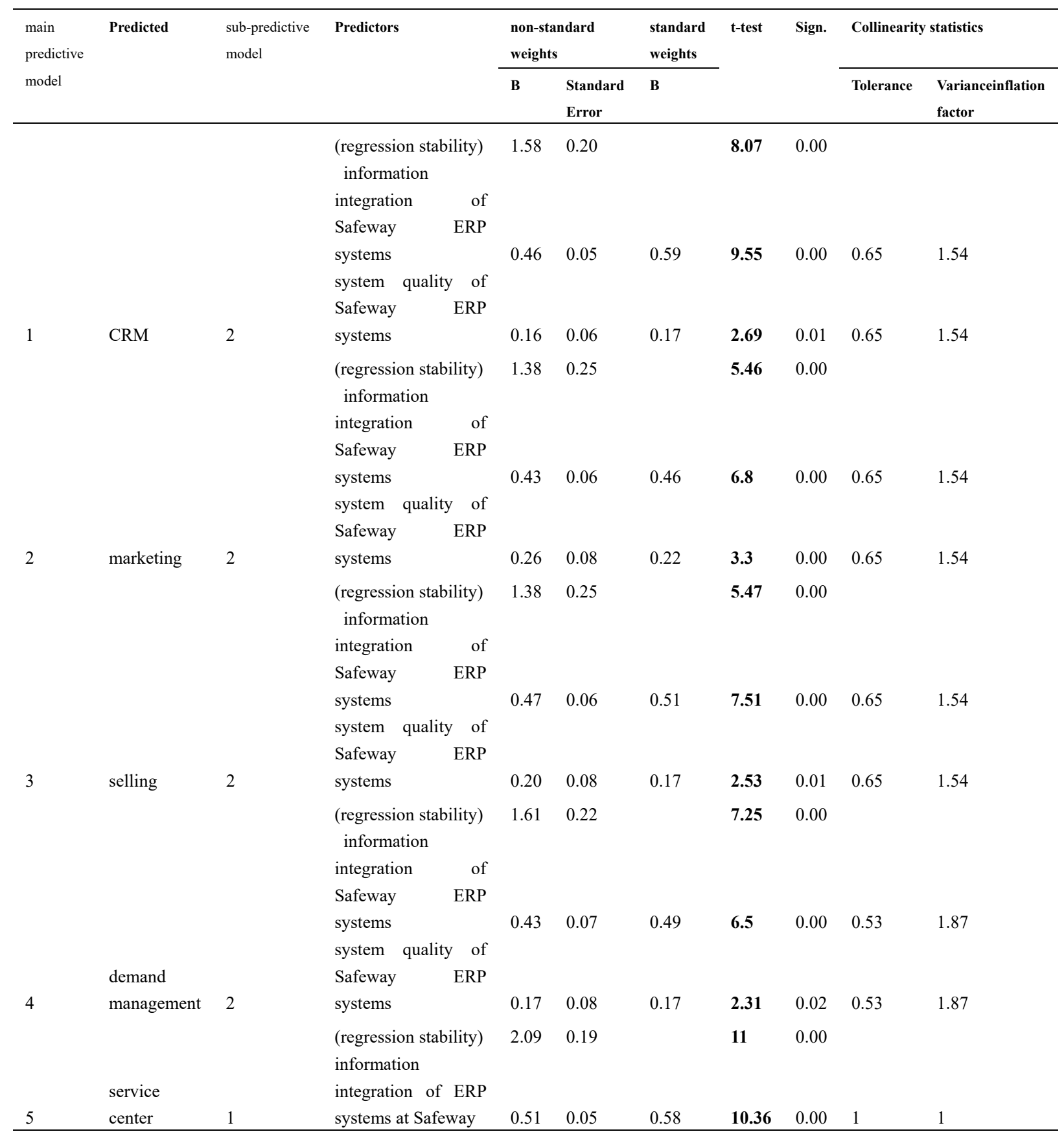

From table 13 it is observed that

1. The increase of information integration dimension of ERP systems by one standard unit from the perspective of Safeway employees increased CRM level by 0.59of the standard unit from Safeway employees perspective, the predictive variable was functional at $(\alpha=0.05)$.

2. The increase of system quality dimension of ERP systems by one standard unit from the perspective of Safeway employees the CRM level increased by 0.17 of the standard unit from Safeway employees perspective, the predictive variable was functional at $(\alpha=0.05)$.

From the above result's it is noticed that the variance inflation factor of the predictive models was low, this result indicates that there is no multicollinearity problem and refers to strong correlations between the predictors. 


\subsection{Results Key Findings}

The results of the first question showed that ERP systems level and its dimensions from the perspective of Safeway employees were high.

The results of the second question showed that the application level of CRM and its dimensions at Safeway was high.

The third question results showed that ERP systems predictive model of CRM and its dimension (marketing, sales, demand management and service center) at Safeway from employees perspective was significant at $\alpha=0.05$ for all the dimensions.

There is a statistically effect of ERP (system quality, information quality, information integration) on marketing at Safeway Company.

There is a statistically effect of ERP (system quality, information quality, information integration) on selling at Safeway Company

There is a statistically effect of ERP (system quality, information quality, information integration) on demand management at Safeway Company.

There is a statistically effect of ERP (system quality, information quality, information integration) on service center at Safeway Company.

\section{Implications}

Based on the results enterprises in general and Safeway in specific administrations are recommended to;

1. Apply ERP systems in enterprises different divisions in general and in CRM divisions in specific.

2. Achieve agreement between ERP systems and the amount of the resources used of hardware, software and devices in a manner that agree with the required.

3. Safeway administrators should connect ERP systems with other systems such as supplier's relationship management system.

\section{References}

Acosta, P. S., Ramayah, T., \& Popa, S. (2013). Explaining Intention to Use an Enterprise Resource Planning System: A replication and Extension. Tehnickivjesnik, 20(3), 397-405.

Baran, R. J., Galka, R. J., \& Strunk, D. P. (2008). Principles of Customer Relationship Management. South Western: Thomson.

Bibiano, L. H., Marco-Simo, J. M., \& Pastor, J. A. (2014). An Initial Approach for Improving CRM Systems Implementation Projects, (CISTI) Iberian Conference on Information Systems \& Technologies. Portugal: Rua de Lagares, Silvares.

Blythe, J. (2006). Marketing. London: SAGE Publications Ltd.

Blythe, J. (2009). Key Concepts in Marketing. Los Angeles, Calif: SAGE Publications Ltd.

Bradford, M. (2014). Modern ERP: Select, Implement, and Use Today's Advanced Business Systems.

Bygstad, B., \& Presthus, W. (2012). Social Media as CRM? How Two Scandinavian Airline Companies Used Facebook during the "Ash Crisis" in 2010. Scandinavian Journal of Information Systems, 25(1), 51-72.

Chopra, S., \& Meindl, P. (2007). Supply Chain Management: Strategy, Planning, And Operation (3rd ed.). Upper Saddle River, New Jersey: Prentice-Hall International, Inc.

Goldenberg, B. J. (2008). CRM in Real Time: Empowering Customer Relationships. Medford, New Jersey: Information Today, Inc.

Haimowitz, I. J. (2011). Healthcare Relationship Marketing Strategy, Design and Measurement. USA, Burlington: Gower Publishing Company.

Hao, L. C. (2013). Application of MVC Platform in Bank E-CRM. International Journal of u- and e- Service, Science and Technology, 6(2), 33-42.

Hasanzadeh, M., \& Mahaleh, S. (2013). Effect of Knowledge Management on Success of Customer Relationship Management in Eghtesad Novin Bank of Tehran. Int. J. Buss. Mgt. Eco. Res., 4(6), 839-848.

Hwang, H. J., \& Park, Y. J. (2013). Kazakhstan Perspectives on ERP System Implementation. International Journal of Software Engineering and Its Applications, 8(4), 223-232. 
Ifinedo, P.,_\& Olsen, D. H. (2015). An Empirical Research on the Impacts of organizational decisions' locus, tasks structure rules, knowledge, and IT function's value on ERP system success. International Journal of Production Research, 53(8), 2554-2568. https://doi.org/10.1080/00207543.2014.991047

Joseph, I. (2013). Service Delivery through Information Systems in Tanroads: Challenges and Possibilities in Dar Es Salaam and Mwanza. Hamburg: Anchor Academic Publishing.

Khlif, H., \& Jallouli, R. (2014). The Sussess Factors of CRM Systems: An Explanatory Analysis. Journal of Global Business and Technology, 2(10), 25-42.

Kostojohn, S., Johnson, M., \& Paulen, B. (2011). CRM Fundamentals. New York: Springer Science \& Business Media. https://doi.org/10.1007/978-1-4302-3591-0

Kubi, B. A., \& Doku, A. K. (2010). Towards a successful customer relationship management: A conceptual framework. African Journal of Marketing Management, 2(3), 37-43.

Kurbel, K. (2013). Enterprise Resource Planning and Supply Chain Management. New York: Springer-Verlag Berlin Heidelberg. https://doi.org/10.1007/978-3-642-31573-2

Lapide, L. (2006). Demand Management Revisited. Journal of Business Forecasting, 25(3), 17-19.

Laudon, K. C., \& Laudon, J. P. (2012). Management Information Systems: Managing the Digital Firm (12th ed.). Upper Saddle River, New Jersey: Prentice-Hall, Inc.

Maleki, M., \& Anand, D. (2008). The Critical Success Factors in Customer Relationship Management $(\mathrm{CRM})(\mathrm{ERP})$ Implementation. Journal of Marketing \& Communication, 4(2), 67-80.

Matenda, S., \& Ogao, P. (2013). Enterprise resource planning (ERP) system implementation: a case for user participation. Procedia Technology, 9(1), 518-526. https://doi.org/10.1016/j.protcy.2013.12.058

Mohammed, A. A., \& Bin, R. B. (2012). Customer Relationship Management (CRM) in Hotel Industry: A framework Proposal on the Relationship among CRM Dimensions, Marketing Capabilities and Hotel Performance. International Review of Management and Marketing, 2(4), 220-230.

Monk, E., \& Wagner, B. (2013). Concepts in Enterprise Resource Planning. Boston: Course Technology, Cengage Learning.

Murthy, C. (2008). Enterprise Resource Planning and Management Information Systems: Text and Case Studies. Mumbai, IND: Himalaya Publishing House. Retrieved from http:/www.ebrary.com

Musyoka, M. R., \& Josphat, K. (2012). Effect of Enterprise Resource Planning in Enhancing Service Delivery in the Procurement Function in Public Universities in Kenya, A Case study of Egerton University-Njoro, Kenya. International Journal of Science and Research (IJSR), 3(10), 37-43.

Odeh, A. (2014). Measurement and Evaluation in the Teaching Process (4th ed.). Jordan, Irbid: Dar Al Amal Publishing.

Oren, S. (2015). How to Select a CRM System. CRM Magazine, 19(4), 28-31.

Parthasarthy, S. (2007). Enterprise Resource Planning: A Managerial and Technical Perspective. Daryaganj, Delhi, IND: New Age International. Retrieved from http:/www.ebrary.com

Peppers, D., \& Rogers, M. (2011). Managing Customer Relationships: A Strategic Framework (2nd ed.), Hoboken, New Jersey: John Wiley \& Sons, Inc.

Qutaishat, F. T., Khattab, S. A., Abu, Z., Mohammed, K., \& Al-Manasra, A. (2012). The Effect of ERP Successful Implementation on Employees' Productivity, Service Quality and Innovation: An Empirical Study in Telecommunication Sector in Jordan. International Journal of Business and Management, 7(19), 45-54. https://doi.org/10.5539/ijbm.v7n19p45

Rodrigues, J. C. (2012). CRM for Dummies. Chichester, England: John Wiley \& Sons Ltd.

Ronchi, A. (2009). Customer Relationship Management. In e Culture-Cultural Content in the Digital Age (pp. 181-182). Berlin: Springer Berlin Heidelberg.

Ruivo, P., Mestrea, A., Johanssonb, B., \& Oliveiraa, T. (2014). Defining the ERP and CRM integrative value. Centeris 2014-Conference on Enterprise Information Systems / International Conference on Project Mmanagement / HCIST 2014 - International Conference on Health and Social Care Information Systems and Technologies. Procedia Technology, 16(1), 704-709. https://doi.org/10.1016/j.protcy.2014.10.019

Sarno, R., Djeni, C. A., Mukhlas, I., \& Sunaryono, D. (2015). Developing a Workflow Management System for 
Enterprise Resource Planning. Journal of Theoretical and Applied Information Technology, 72(3), 412-421.

Sebjan, U., Bobek, S., \& Tominc, P. (2014). Organizational factors influencing effective use of CRM solutions. Procedia Technology, 16, 459-470. https://doi.org/10.1016/j.protcy.2014.10.113

Simunovic, K., Šimunović, G., Havrlišan, S., Pezer, D., \& Svalina, I. (2013). The Role of Erp System in Business Process and Education. Tehničkivjesnik, 20(4), 711-719.

Singla, A. R. (2008). Impact of ERP Systems on Small and Midsized Public Sector Enterprises. Journal of Theoretical and Applied Information Technology, 4(2), 119-131.

Soliman, H. S. (2011). Customer Relationship Management and Its Relationship to the Marketing Performance. International Journal of Business and Social Science, 2(10), 166-182.

Tian, F., \& Xu, S. X. (2015). How Do Enterprise Recourse Planning Systems Affect Firm Risk? Post-Implémentation Impact. MIS Quarterly, 39(1), 39-60. https://doi.org/10.25300/MISQ/2015/39.1.03

Tsai, B. H., \& Chou, S. (2015). Application of Multiple Output Data Envelopment Analysis in Interpreting Efficiency Improvement Of Enterprise Resource Planning Integrated Circuit Firms. The Journal of Developing Areas, 49(1), 285-304. https://doi.org/10.1353/jda.2015.0037

Tsaia, W. H., Leea, K. C., Liub, J. Y., Lina, S. J., \& Choua, Y. W. (2012). The influence of enterprise resource planning (ERP) systems performance on earnings management. Enterprise Information Systems, 6(4), 491-517. https://doi.org/10.1080/17517575.2011.622414

Veldhoven, R. H. M. V., \& Roermund, A. H. M. V. (2011). System Quality Indicators. In M. Ismail \& M. Sawan (Eds.), Robust Sigma Delta Converters (pp. 13-26). Netherlands: Springer. https://doi.org/10.1007/978-94-007-0644-6_2

Wang, R. Y., Pierce, E. M., \& Madnick, S. E. (2005). Information Quality (Advances in Management Information Systems). Armonk, NY, USA: M.E. Sharpe, Inc. Retrieved from http: www.ebrary.com

Wang, S. H., \& Wang, H. (2014). A Survey of Open Source Enterprise Resource Planning (ERP) Systems. International Journal of Business and Information, 9(1), 1-28.

Wittemann, M., \& Ables, G. (2011). Microsoft Dynamics CRM 2011 Administration Bible. Indiana, Indianapolis: Wiley Publishing Inc.

Wong, C. W. Y., Lai, K. H., \& Cheng, T. C. E. (2011). Value of Information Integration to Supply Chain Management: Roles of Internal and External Contingencies. Journal of Management Information Systems, 28(3), 161-199. https://doi.org/10.2753/MIS0742-1222280305

Yen, T. S., Idrus, R., \& Yusof, U. K. (2014). A Framework for Classifying Misfits between Enterprise Resource Planning (ERP) Systems and Business Strategies. Asian Academy of Management Journal, 16(2), 53-75.

Zentes, J., Morschett, D., \& Schramm, K. H. (2011). Strategic Retail Management (2nd ed.). Deutsche: Springer Fachmedien Wiesbaden

Zimmerman, W. (2015). Perception of a Difference: The Power in Buying, Marketing and Selling Customer Care. Scottsdale, AZ, USA: WZA, Incorporated.

\section{Copyrights}

Copyright for this article is retained by the author(s), with first publication rights granted to the journal.

This is an open-access article distributed under the terms and conditions of the Creative Commons Attribution license (http://creativecommons.org/licenses/by/4.0/). 